\title{
Pharmacists' Preparedness to Patients Education at the Time of Pandemic-A Cross-Sectional Study with an Example of SARS-CoV-2 Outbreak in Poland
}

\author{
Magdalena Cerbin-Koczorowska ${ }^{1, *(\mathbb{D})}$, Magdalena Waszyk-Nowaczyk ${ }^{2}(\mathbb{D}$ and \\ Piotr Przymuszała 1 (1) \\ 1 Department of Medical Education, Poznan University of Medical Sciences, 7 Rokietnicka St, 60-806 Poznan, \\ Poland; pprzymuszala@ump.edu.pl \\ 2 Department of Pharmaceutical Technology, Pharmacy Practice Division, Poznan University of Medical \\ Sciences, 6 Grunwaldzka St, 60-780 Poznan, Poland; mwaszyk@ump.edu.pl \\ * Correspondence: mcerbin@ump.edu.pl
}

Received: 27 August 2020; Accepted: 10 September 2020; Published: 12 September 2020

\begin{abstract}
Although pharmacy employees' involvement in patient education has great potential, the extent to which they actually provide cognitive services seems inadequate. Given the overburdening of the healthcare system and limited access to medical services due to the severe acute respiratory syndrome coronavirus 2 (SARS-CoV-2) pandemic outbreak, this study aimed to evaluate the preparedness of Polish pharmacy employees for patient education on the new threat. The study was conducted using the mystery shopper method. Two interviewers phoned 90 randomly chosen community pharmacies throughout Poland and presented some inquiries on the SARS-CoV-2. Pharmacists devoted more time to patients than pharmacy technicians (2:22 vs. 1:54), and the information they provided was significantly more comprehensive $(p=0.006)$. The majority of respondents provided an evidence-based recommendation on prevention, symptoms, and management of SARS-CoV-2; however, the scope of advice significantly varied. Community pharmacy staff often expressed their concern about the lack of time to address patients' questions adequately. No statistically significant differences were found in recommendations provided by chain and non-chain pharmacy staff. Obtained results seem to confirm the possibility of involving pharmacists in public health activities during a pandemic. Nevertheless, providing proper working conditions and adequate just-in-time learning solutions is crucial.
\end{abstract}

Keywords: COVID-19; pandemic; community pharmacy; pharmaceutical services; patient education; health promotion; mystery shopper

\section{Introduction}

The availability and frequency with which patients visit community pharmacies in comparison with other healthcare facilities places their employees among the first healthcare professionals contacted by patients with inquiries on health-related issues [1-3]. This process is additionally reinforced by the limited access to medical services, which prompts patients to search for other sources of information or medical assistance. Consequently, changing societal expectations influenced the pharmacists' scope of practice. The scope of contemporary pharmacy practice should not be reduced to dispensing drugs but also involve the pharmaceutical care, sharing pharmacists' expertise on drugs with patients and other members of the medical team, and broadly understood health education of patients, including the disease prevention and promotion of healthy eating and lifestyle [4-7]. Studies conducted previously already noted pharmacists' engagement in patient education on, among others, rational antibiotic 
treatment, healthy lifestyle, sleep problems, or quitting smoking [2,8-11]. However, other reports show inadequate involvement of pharmacists in patient health education despite their high recognition of its necessity [12-14]. Potential reasons for that discrepancy might include limited time and human resources, lack of remuneration for their additional services, or fears of stepping into the physician's scope of practice [12,14,15].

Meanwhile, although Polish patients still connect pharmacists mostly with selling medicaments [16], there are reports indicating patients' positive attitudes and expectations for pharmacists' advice or information on drugs, smoking cessation, and minor or chronic health conditions, including their screening and prevention $[17,18]$. The majority of Polish pharmacists also express positive attitudes and readiness to expand the scope of their practice $[19,20]$. However, at the same time, they seem to have an unclear idea of their educatory role [19]. Moreover, the extent to which such services are actually provided remains unsatisfactory in the opinion of the majority of Polish patients [16]. Currently, there are no cognitive services implemented in Polish pharmacies, e.g., vaccinations or advice on smoking cessation services that would be financed by the public insurer. This can affect the perception of pharmacists' image as producers or dispensers of drugs, and although they provide expert information about them, most of these activities are still more product-focused than patient-centered.

The Severe acute respiratory syndrome coronavirus 2 (SARS-CoV-2) pandemic outbreak caused an unprecedented burden to the healthcare systems worldwide, additionally limiting the access of patients to medical services. Overworked physicians and other healthcare workers might not be able to admit all patients seeking medical attention, especially in minor cases. Due to the novelty of the SARS-CoV-2, some patients might also search for professional information on the new threat. Meanwhile, pharmacists already played a significant role during the 2009 H1N1 pandemic. Their specialized skill set and knowledge allowed them to provide patient education that may increase vaccination rates but also improve public health emergency response efforts [21].

Taking all of the above into account, this study aimed to evaluate the readiness and preparedness of Polish pharmacy employees to provide their patients with essential information on the SARS-CoV-2.

\section{Materials and Methods}

The study was conducted in March 2020 using the "mystery shopper" (MS) methodology that allows evaluating the performance of healthcare providers [22]. The roles of patients were portrayed by the first and second researchers, both female in their mid-thirties and with previous experience in interviewing pharmacists, telephone interviewing, and the MS method. Data were collected within four working days according to the structured scenario designed by the main researcher and reviewed by two other community pharmacists. Due to the dynamic situation, efforts were made to collect data without unnecessary delays to avoid the potential impact of rapidly changing variables on the collected data. In order to avoid a scenario bias described previously [23], we adapted one scenario that was used by both MS. The consultation scenario and the data collection form were previously discussed by interviewers to minimize the researcher bias. The structured scenario involved MS presenting some concerns about the SARS-CoV-2 outbreak followed by asking the pharmacist about prevention, symptoms, and management of the SARS-CoV-2 infection. The scheme of consultation scenario was presented in Figure 1.

Interviewers phoned a sample of 90 randomly chosen community pharmacies throughout Poland, respecting the proportion between the number of pharmacies in different provinces. The detailed characteristics of pharmacies whose employees provided the consultation are presented in Table 1. 


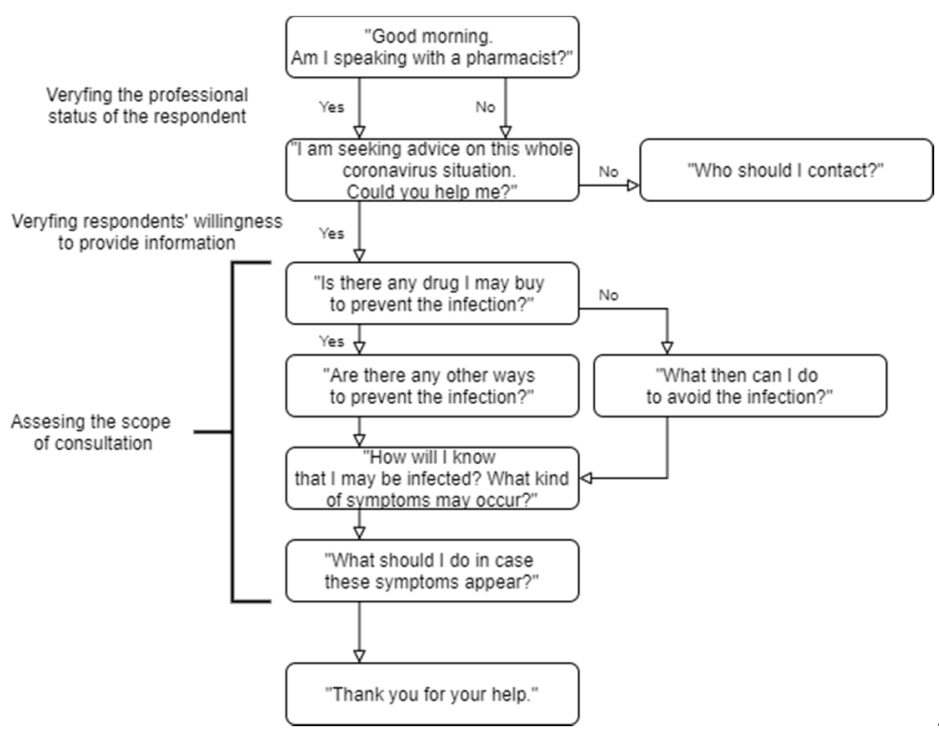

Figure 1. The scheme of consultation scenario which served as a guide for "mystery shopper" consultation.

Table 1. Characteristics of randomly chosen community pharmacies.

\begin{tabular}{lc}
\hline \multicolumn{1}{c}{ Characteristic } & $\boldsymbol{n} \mathbf{( \% )}$ \\
\hline Province [in Polish] (total number of community pharmacies) & \\
Lower Silesian [dolnośląskie] (991) & $6(8.70)$ \\
Kuyavian-Pomeranian [kujawsko-pomorskie] (611) & $3(4.35)$ \\
Lublin [lubelskie] (785) & $5(7.25)$ \\
Lubusz [lubuskie] (331) & $1(1.45)$ \\
Łódź [łódzkie] (855) & $5(7.25)$ \\
Lesser Poland [małopolskie] (1073) & $6(8.70)$ \\
Masovian [mazowieckie] (1701) & $10(14.49)$ \\
Opole [opolskie] (310) & $1(1.45)$ \\
Subcarpathian [podkarpackie] (665) & $3(4.35)$ \\
Podlaskie [podlaskie] (387) & $2(2.90)$ \\
Pomeranian [pomorskie] (704) & $5(7.25)$ \\
Silesian [śląskie] (1437) & $10(14.49)$ \\
Holy Cross [świętokrzyskie] (393) & $2(2.90)$ \\
Warmian-Masurian [warmińsko-mazurskie] (418) & $2(2.90)$ \\
Greater Poland [wielkopolskie] (1278) & $5(7.25)$ \\
West Pomeranian [zachodniopomorskie] (560) & $3(4.35)$ \\
\hline Exact location a & \\
\hline large towns & $20(28.99)$ \\
medium towns & $17(24.64)$ \\
small towns & $21(30.43)$ \\
villages & $11(15.94)$ \\
\hline non-chain & \\
\hline pharmacy b & $18(26.09)$ \\
\hline phain & $51(73.91)$ \\
\hline
\end{tabular}

a Small towns-population below 20,000 inhabitants; medium towns-population 20,000-100,000 inhabitants; large towns-population above 100,000 inhabitants. $^{b}$ chain $\geq 5$ pharmacies under the same brand.

Answers provided by pharmacists were noted directly during the interview with the use of a data collection form prepared according to the recommendations issued by the Polish Ministry of Health [24] and entered into Microsoft Excel 2016 (Microsoft Company, the United States). Data were further analyzed with the U-Mann-Whitney test and Fisher's exact test (two-tailed), as appropriate, 
using the Statistical Software (version 13.3) (TIBCO Software Inc., Palo Alto, USA). For $2 \times 4$ tables, the Freeman-Halton extension of the Fisher exact probability test was applied using the VassarStats website [25]. Statistical significance was set at $p<0.05$.

Whether the pharmacist who provided the consultation was employed in a chain or a non-chain pharmacy was verified using the registry of pharmacies [26]. Due to its volume of more than 22,000 entries, an authorial code in Python was used. A chain was defined as five or more pharmacies having the same owner [27], which was confirmed comparing their Taxpayer Identification Numbers (in Polish: Numer Identyfikacji Podatkowej, NIP). The study protocol was approved by the Institutional Review Board.

\section{Results}

In 54 pharmacies, the phone was answered at the first attempt. In 12 pharmacies, no one answered despite three attempts made with at least $10 \mathrm{~min}$ intervals. Out of the total 78 phone calls, 59 were conducted with pharmacists (PH) $(84.75 \%$ female) and another 19 with pharmacy technicians (T) (78.95\% female). Seven interviewees were initially not willing to talk, but in the end, they agreed to provide the MS with the information needed. Nine respondents $(\mathrm{nPH}=5, \mathrm{nPT}=4)$ refused to provide the consultation. Among respondents who refused to provide the consultation, three were employed in large towns, three in medium-size towns, one in a small town, and two in villages. All of them were employed in non-chain pharmacies.

The differences in the willingness of employees to provide the consultation were not statistically significant for both the town size $(p=0.6890)$ and the chain or non-chain pharmacies $(p=0.1078)$. No statistically significant differences were observed between the respondents who provided and refused to provide the consultation in terms of their gender $(p=0.1671)$ and whether they were a pharmacist or a technician ( $p=0.2097)$.

The leading cause of the refusal $(66.67 \%)$ was the lack of time to give full information resulting from the need to help patients who were present in the pharmacy at the time of the consultation. However, refusing respondents usually indicated the possibility of obtaining reliable information at the Ministry of Health and Chief Sanitary Inspectorate websites. A total of 69 consultations was provided by pharmacy staff $(\mathrm{nPH}=54, \mathrm{nPT}=15)$. The average time of single consultation was $2 \mathrm{~min}$ and $16 \mathrm{~s}$ (range from 1:04 to 3:50). Ratios and frequencies were employed as descriptive analyses of the results and presented in Table 2 for answers provided by pharmacists and pharmacy technicians.

Keeping a safe distance was the most frequently recommended way of lowering the risk of contracting coronavirus, followed by hand hygiene. In response to this question, more detailed information was generally provided by pharmacists than pharmacy technicians.

The majority of pharmacists and pharmacy technicians correctly listed the most common symptoms of the COVID-19 infection. Fever was indicated most often. Pharmacists statistically more often mentioned breathing difficulties as one of the symptoms $(p=0.033)$.

In response to the question "What should do in case of those symptoms appear?" both groups most often recommended contacting the Chief Sanitary Inspectorate. The second most common answers were in the case of pharmacists a local isolation ward and in the case of technicians the National Health Fund hotline. Contrary to the Ministry's recommendations, some respondents also recommended visiting or contacting an emergency ward or calling the emergency number.

No statistically significant differences were found in recommendations provided by chain and non-chain pharmacy staff. 
Table 2. Recommendations for patients provided by pharmacists and pharmacy technicians.

\begin{tabular}{|c|c|c|c|c|c|c|}
\hline & Consultations Details & & Pharmacists & $\begin{array}{c}\text { Pharmacy } \\
\text { Technicians }\end{array}$ & Total $^{\text {a }}$ & \\
\hline & Number of consultations & & $54(100.00)$ & $15(100.00)$ & $69(100.00)$ & \\
\hline & Average time of a single consultation & & $2: 22$ & $1: 54$ & $2: 16$ & \\
\hline Category & Information Provided by Pharmacy Staff & & & & & $p$-value \\
\hline \multirow{9}{*}{ Prevention } & Keep safe distance & & $51(94.44)$ & $12(80.00)$ & $63(91.30)$ & 0.112 \\
\hline & Wash your hands often & & $43(79.63)$ & $9(60.00)$ & $52(75.36)$ & 0.174 \\
\hline & alcohol-based liquids/gels & & $27(50.00)$ & $4(26.67)$ & $31(44.93)$ & 0.146 \\
\hline & water with soap & & $27(50.00)$ & $3(20.00)$ & $30(43.48)$ & 0.045 \\
\hline & Avoid touching eyes, nose and mouth & & $17(31.48)$ & $1(6.67)$ & $18(26.09)$ & 0.093 \\
\hline & Cover mouth/nose while sneezing/coughing & & $9(16.67)$ & $0(0.00)$ & $9(13.04)$ & 0.189 \\
\hline & the average number of information & Q1 & 2 & 1 & 2 & \multirow{3}{*}{0.006} \\
\hline & provided by a single resnondent & Q2 & 3 & 2 & 3 & \\
\hline & & Q3 & 6 & 3 & 6 & \\
\hline Drug usage & No drug helps to prevent the infection & & $45(83.33)$ & $8(53.33)$ & $53(76.81)$ & 0.033 \\
\hline \multirow{6}{*}{ Symptoms } & fever & & $49(90.74)$ & $13(86.67)$ & $62(89.86)$ & 0.641 \\
\hline & breathing difficulties & & $45(83.33)$ & $8(53.33)$ & $53(76.81)$ & 0.033 \\
\hline & dry cough & & $36(66.67)$ & $12(80.00)$ & $48(69.57)$ & 0.527 \\
\hline & the average number of information & Q1 & 2 & 2 & 2 & \multirow{3}{*}{0.222} \\
\hline & the average number of information & $\mathrm{Q} 2$ & 3 & 2 & 2 & \\
\hline & provided by a single respondent & Q3 & 3 & 3 & 3 & \\
\hline \multirow{9}{*}{ Source of aid } & Chief Sanitary Inspectorate & & $40(74.07)$ & $8(53.33)$ & $48(69.57)$ & 0.203 \\
\hline & isolation ward at the local hospital & & $28(51.85)$ & $4(26.67)$ & $32(46.38)$ & 0.142 \\
\hline & National Health Fund hotline & & $14(25.93)$ & $6(40.00)$ & $20(28.99)$ & 0.341 \\
\hline & emergency ward at the local hospital & & $4(7.41)$ & $1(6.67)$ & $5(7.25)$ & 0.999 \\
\hline & emergency telephone number (112) & & $3(5.56)$ & $0(0.00)$ & $3(4.35)$ & 0.999 \\
\hline & local physician's office & & $2(3.70)$ & $1(6.67)$ & $3(4.35)$ & 0.527 \\
\hline & & Q1 & 1 & 1 & 1 & \multirow{3}{*}{0.141} \\
\hline & the average number or inrormation & Q2 & 2 & 1 & 2 & \\
\hline & & Q3 & 2 & 2 & 2 & \\
\hline
\end{tabular}

a Respondents could choose more than one answer. The results do not add up to $100 \%{ }^{\text {b }}$ including only correct answers. Q-question; A-provided answers; Q1—lower quartile; $\mathrm{Q} 2-$ middle quartile; $\mathrm{Q} 3-$ upper quartile. Statistically significant differences at $p<0.05$ are presented in bold. 


\section{Discussion}

The results of this study demonstrate the readiness and preparedness of most pharmacists and pharmacy technicians to provide patient education during the pandemic outbreak. Most respondents managed to answer MS's questions satisfactorily, providing at least half of expected correct answers, which signifies the potential of their involvement in similar situations. Some differences, however, were observed between the quality of the information provided by pharmacy employees depending on their qualifications.

In Poland, pharmacy staff may consist of either Master of Pharmacy (pharmacists) or pharmacy technicians. Pharmacists, in order to obtain the license to practice their profession, must complete 5years of studies, followed by a six-month work placement, which is obligatory in order to graduate. Pharmacists are also obliged to improve their qualifications in the course of further professional work as part of continuous training. On the other hand, the diploma of a pharmacy technician is obtained after 2 years of training, after which they begin a 2-year professional internship.

Sancar et al. [23] also compared the quality of advice provided by different employees of community pharmacies. Although there were no significant differences between the number of pharmacists and pharmacy technicians who provided the consultation, the advice of pharmacists was more comprehensive.

Better preparation of pharmacists to be involved in patient education seems to be a reflection of differences in curricula. The profile of the pharmacy graduate assumes using their knowledge and skills in areas related to disease prevention as well as their readiness to promote pro-health behavior [28]. On the other hand, the professional qualifications of pharmacy technicians concern the "preparation and production of medicinal products and trading medicinal products (...) in a pharmacy" [29].

The relationship between the level of education of pharmacy staff and the quality of patient counselling was identified in previously conducted studies [30]. Noteworthy, in the analysis conducted by Koehler and Brown [31] in 67 countries, it was shown that only a small percentage of pharmacy-technician learners are satisfied with the quality of their education. In our study, some shortcomings and deficiencies were observable during the consultations. For instance, some of the provided information was inconsistent with the Ministry's recommendations. This may be due to the fact that the SARS-CoV-2 is a new virus, and thus, reliable information on it was not as easily accessible as in the case of other diseases. The extension of the average working time of pharmacy employees resulting from reduced access to professional staff [32] makes it even more difficult to find enough time to fill knowledge gaps.

On 11 March 2020, a week after the first case of coronavirus was detected in Poland, the Supreme Pharmaceutical Chamber published on its website [33] educational materials for pharmacists, including guidelines developed by the Chief Sanitary Inspectorate. The currently existing one-way communication paths between the pharmacy chambers and pharmacies make it difficult to verify to what extent the professional staff got acquainted with the available materials.

It may be worth considering setting up a central LMS (learning management system) platform enabling effective management of the educational process in accordance with the qualifications of pharmacy employees. A systematic review performed by Salter et al. [34] on the topic of e-learning use for continuing pharmacy education confirmed an increase in knowledge immediately after training, regardless of the topic and form. The same observations in the Polish study group were made by the team of Nesterowicz et al. [35], also confirmed by high satisfaction among participants.

Currently, the majority of educational activities intended as part of continuous training, although aimed at maintaining high-quality patient care, are organized outside the working context. Meanwhile, Coppus et al. [36] proved the use of distance learning tools in pharmacy education allows "to provide just-in-time learning through on-the-job-training, with the potential for teaching and learning to directly impact on practice". Moreover, the use of remote tools allows to quickly reach learners who live in geographically diverse areas [34]. 
Our results also show that the complexity of the advice provided varies greatly between the members of the study group. In some cases, respondents provided only one answer to the given question. However, it should be emphasized that in Poland, pharmacy employees still rarely provide such cognitive services other than giving drug-related advice. It seems that educational materials for pharmacists should, therefore, be more orientated to form a dedicated consultation pathway, similar to one designed by Amariles et al. [37].

Despite the positive attitudes of patients and doctors concerning the involvement of pharmacists in patient education $[18,38]$, previous studies may suggest pharmacists' low self-esteem in this area (unpublished results). Despite the aforementioned advantages of e-learning, its usefulness in shaping attitudes and skills is limited. Meanwhile, the use of simulated-patient (SP) methods allows for maintaining the benefits of a work-based context while focusing on skills and competency domains. The SP method involves re-enacting a previously designed scenario with the participation of a pharmacist-learner and an actor in the role of a patient. It was proven that the implementation of this method in the pharmacy curriculum could effectively build self-confidence and improve the comfort of working with patients [39]. Unfortunately, the use of the SP method in teaching future pharmacists in Poland is still limited.

Another striking result to emerge from the data is that many representatives of pharmacy staff expressed their concerns about the lack of time to address patients' questions adequately. Polish media are currently raising the alarm about the decreasing number of available pharmacy staff, with a simultaneous abrupt increase in the number of patients [40]. Previously conducted studies from various countries, including Poland, show that despite pharmacists' openness to involvement in the provision of cognitive services, including patient health education, they often mention the lack of time, among others, as barriers to its popularization [41,42]. Moreover, at the time of difficulties in access to primary care physicians, pharmacists are taking on further responsibilities related to, for example, issuing prescriptions for Rx drugs. Eades et al. [6] indicated that pharmacists often view their traditional role of drug dispensing as more important than engaging in health education. The majority of respondents in our study, however, provided at least primary, evidence-based recommendations. However, pharmacy managers should be encouraged to delegate administrative work to pharmacy technicians and to take advantage of pharmacists' intellectual potential for patient education and counselling.

Available evidence supports the value of professional pharmacy services, including patient education. Ung [43] even stated that "community pharmacists have a key role in preventing the spread of the 2019-CoV virus. They are charged with key responsibilities of informing, advising and educating the community (...)". Nevertheless, the results of studies conducted at the time when the cognitive services were being popularized in Australia and the USA indicated that broadening the range of duties should be accompanied not only by training but also by providing pharmacists with proper working conditions and remuneration [44].

Meanwhile, in the initial phases of the pandemic, the Polish authorities expected pharmacy owners to ensure the safety of pharmacists while performing their professional duties. Only after the intervention of the Pharmaceutical Chamber, the government support was extended on community pharmacies staff [45]. Similarly, when the government decided to reimburse flu vaccines for healthcare professionals, community pharmacists were not initially included in this group [46]. These situations seem to suggest that Polish policy-makers do not perceive pharmacists on a par with other healthcare representatives.

On further analysis of the working conditions of community pharmacists, several other factors significantly impeding the reform of pharmacy practice can be identified. Firstly, although pharmaceutical care was legally introduced in 2008 [47], there is a lack of precisely identified scope of services that could be realized in it. Despite successive teams of experts for the implementation of pharmaceutical care in Poland, still, no measurable actions have been taken [48]. 
Secondly, despite the ongoing process to pass the Pharmacy Profession Act, which would regulate the pharmacist's rights and duties related to the provision of patient-centered care, so far, nothing has been established [49].

The resistance of representatives of other healthcare professions also seems to be not without significance, which may result from the physician-centered model of healthcare in Poland [50]. Many physicians are convinced that pharmacists control their work while, in fact, they support their actions and increase the safety of patients' pharmacotherapy [51].

Finally, the issue of remuneration cannot be ignored. The data for 2019 show that the average net salary of a Master of Pharmacy in Poland ranged from PLN 3500 in non-chain pharmacies to PLN 3800 in chains with more than 30 pharmacies [52]. Despite the fact that pharmacists stand on the front lines during the pandemic, any reported increases in their salaries are related only to the attendance bonuses [53]. It is also worth noting that although pharmaceutical services bring many economic benefits and savings for health care, the National Health Fund still does not make decisions in this regard [54,55].

\section{Study Limitations}

The findings of this study have to be seen in the light of some limitations. Due to the dynamically changing epidemiological situation, the researchers decided to collect data as quickly as possible to avoid the influence of other variables on the results obtained. As a result, data were obtained from a limited number of respondents, which prevents their generalization to the entire study population. For the results to be representative on a national scale, the study group should be enlarged to a representative number of 379 community pharmacies [56].

Coronavirus is a new health challenge for the entire world. Therefore, access to reliable knowledge sources in the first months of the pandemic was significantly limited. Consequently, it would be worthwhile to evaluate the sources from which healthcare workers, including pharmacy staff, obtain professional knowledge.

Moreover, due to the SARS-CoV-2 outbreak, it was not possible to conduct this study using the classic MS in community pharmacy visits. In order to ensure the maximum safety of the interviewers, it was decided to conduct the survey using telephone calls. For this reason, in this study, we focused on the content of the consultation. It seems valuable to supplement the data with the assessment of pharmacy staff's non-technical skills that may affect the effectiveness of patient education.

\section{Conclusions}

Pharmacists are willing to engage in patient education activities during a pandemic. However, it is crucial to reorganize their working conditions so that they can use their intellectual potential to care for the patient without neglecting other duties. Efforts should also be made to introduce appropriate just-in-time learning solutions to provide pharmacy employees with up-to-date, evidence-based knowledge, especially in case of a new threat or crisis.

Author Contributions: Conceptualization, M.C.-K.; methodology, M.C.-K.; software, P.P.; validation, M.C.-K., M.W.-N., and P.P.; formal analysis, P.P.; investigation, M.C.-K. and M.W.-N.; resources, M.C.-K., M.W.-N., and P.P.; data curation, P.P.; writing-original draft preparation, M.C.-K., M.W.-N., and P.P; writing—review and editing, M.C.-K., M.W.-N., and P.P.; visualization, M.C.-K.; supervision, M.C.-K.; project administration, M.C.-K. and M.W.-N.; funding acquisition, M.C.-K. All authors have read and agreed to the published version of the manuscript.

Funding: This research was funded by the Poznan University of Medical Sciences, grant number 502-0103314429-03439 and 502-14-04102108-09985. The APC was funded by the Poznan University of Medical Sciences.

Acknowledgments: The authors would like to thank all pharmacists who participated in the study and Tomasz Goslinski for his support and invaluable tips.

Conflicts of Interest: The authors declare no conflict of interest. The funders had no role in the design of the study; in the collection, analyses, or interpretation of data; in the writing of the manuscript; or in the decision to publish the results. 


\section{References}

1. Awad, A.I.; Al-Rasheedi, A.; Lemay, J. Public Perceptions, Expectations, and Views of Community Pharmacy Practice in Kuwait. Med. Princ. Pract. 2017, 26, 438-446. [CrossRef] [PubMed]

2. Al Aqeel, S.; Abanmy, N.; AlShaya, H.; Almeshari, A. Interventions for Improving Pharmacist-Led Patient Counselling in the Community Setting: A Systematic Review. Syst. Rev. 2018, 7, 1-13. [CrossRef] [PubMed]

3. Hindi, A.M.K.; Schafheutle, E.I.; Jacobs, S. Patient and Public Perspectives of Community Pharmacies in the United Kingdom: A Systematic Review. Health Expect. 2018, 21, 409-428. [CrossRef] [PubMed]

4. Hepler, C.; Strand, L. Opportunities and Responsibilities in Pharmaceutical Care. Am. J. Hosp. Pharm. 1990, 47, 533-542. [CrossRef] [PubMed]

5. World Health Organization. Joint FIP/WHO Guidelines on Good Pharmacy Practice: Standards for Quality of Pharmacy Services. WHO Tech. Rep. Ser. 2011, 961, 1-18.

6. Eades, C.E.; Ferguson, J.S.; O'Carroll, R.E. Public Health in Community Pharmacy: A Systematic Review of Pharmacist and Consumer Views. BMC Public Health 2011, 11, 582. [CrossRef]

7. Pearson, G.J. Evolution in the Practice of Pharmacy-Not a Revolution! Cmaj 2007, 176, 1295-1296. [CrossRef]

8. Douglas, E.; Power, A.; Hudson, S. Pharmaceutical Care of the Patient with Diabetes Mellitus: Pharmacists' Priorities for Services and Educational Needs in Scotland. Int. J. Pharm. Pract. 2007, 15, 47-52. [CrossRef]

9. Simpson, S.H.; Haggarty, S.; Johnson, J.A.; Schnidel, T.J.; Tsuyuki, R.T.; Lewanczuk, R. Survey of Pharmacist Activities and Attitudes in Diabetes Management. Can. Pharm. J. 2009, 142, 128-134. [CrossRef]

10. Blom, L.; Krass, I. Introduction: The Role of Pharmacy in Patient Education and Counseling. Patient Educ. Couns. 2011, 83, 285-287. [CrossRef]

11. Sakeena, M.H.F.; Bennett, A.A.; McLachlan, A.J. Enhancing Pharmacists' Role in Developing Countries to Overcome the Challenge of Antimicrobial Resistance: A Narrative Review. Antimicrob. Resist. Infect. Control 2018, 7. [CrossRef] [PubMed]

12. Fang, Y.; Yang, S.; Feng, B.; Ni, Y.; Zhang, K. Pharmacists' Perception of Pharmaceutical Care in Community Pharmacy: A Questionnaire Survey in Northwest China. Health Soc. Care Community 2011, 19, $189-197$. [CrossRef] [PubMed]

13. Laliberté, M.C.; Perreault, S.; Damestoy, N.; Lalonde, L. Ideal and Actual Involvement of Community Pharmacists in Health Promotion and Prevention: A Cross-Sectional Study in Quebec, Canada. BMC Public Health 2012, 12, 192. [CrossRef] [PubMed]

14. Goldstone, L.W.; Saldaña, S.N.; Werremeyer, A. Pharmacist Provision of Patient Medication Education Groups. Am. J. Health Pharm. 2015, 72, 487-492. [CrossRef]

15. San Martín-Rodríguez, L.; Beaulieu, M.-D.; D'Amour, D.; Ferrada-Videla, M. The Determinants of Successful Collaboration: A Review of Theoretical and Empirical Studies. J. Interprof. Care 2005, 19 (Suppl. 1), $132-147$. [CrossRef]

16. Majchrowska, A.; Bogusz, R.; Nowakowska, L.; Pawlikowski, J.; Piątkowski, W.; Wiechetek, M. Public Perception of the Range of Roles Played by Professional Pharmacists. Int. J. Environ. Res. Public Health 2019, 16, 2787. [CrossRef]

17. Goniewicz, M.L.; Lingas, E.O.; Czogala, J.; Koszowski, B.; Zielinska-Danch, W.; Sobczak, A. The Role of Pharmacists in Smoking Cessation in Poland. Eval. Health Prof. 2010, 33, 81-95. [CrossRef]

18. Waszyk-Nowaczyk, M.; Łuczak, A.; Michalak, D.; Kaczmarczyk, J.; Myrda, H.; Michalak, M.; Ratka, A. Evaluation of opinions on community pharmacy-based health screenings for common chronic diseases. Acta Pol. Pharm. Drug Res. 2017, 74, 1613-1620.

19. Pawłowska, I.; Pawłowski, L.; Lichodziejewska-Niemierko, M. The Role of a Pharmacist in a Hospice: A Nationwide Survey among Hospice Directors, Pharmacists and Physicians. Eur. J. Hosp. Pharm. 2016, 23, 106-112. [CrossRef]

20. Waszyk-Nowaczyk, M.; Skura, O.; Michalak, M.; Ratka, A. Opinions of pharmacists on community pharmacy-based health screenings for common chronic diseases. Acta Pol. Pharm.Drug Res. 2018, 75, 819-826.

21. Rubin, S.E.; Schulman, R.M.; Roszak, A.R.; Herrmann, J.; Patel, A.; Koonin, L.M. Leveraging Partnerships among Community Pharmacists, Pharmacies, and Health Departments to Improve Pandemic Influenza Response. Biosecurity Bioterrorism 2014, 12, 76-84. [CrossRef] [PubMed]

22. Chandra-Mouli, V.; Lenz, C.; Adebayo, E.; Lang Lundgren, I.; Gomez Garbero, L.; Chatteriee, S. A Systematic Review of the Use of Adolescent Mystery Clients in Assessing the Adolescent Friendliness of Health Services in High, Middle, and Low-Income Countries. Glob. Health Action 2018, 11, 1536412. [CrossRef] [PubMed] 
23. Sancar, M.; Tezcan, E.; Okuyan, B.; Izzettin, F.V. Assessment of the Attitude of Community Pharmacists and Pharmacy Technicians towards Diarrhea: A Simulated Patient Study in Turkey. Trop. J. Pharm. Res. 2015, 14, 1509-1515. [CrossRef]

24. Ministry of Health. Coronavirus-What Do You Need to Know? [in Polish: Koronawirus—Co musiszwiedzieć?]. Available online: https://www.gov.pl/web/zdrowie/co-musisz-wiedziec-o-koronawirusie (accessed on 5 August 2020).

25. VassarStats: Statistical Computation Web Site. Available online: http://vassarstats.net/fisher2x4.html (accessed on 7 September 2020).

26. Polish Medical Registers—Registry of Pharmacies. Available online: https://rejestrymedyczne.csioz.gov.pl/ $\mathrm{ra} /$ search/public (accessed on 12 August 2020).

27. IQVIA. Report for September 2019. Available online: https://www.nia.org.pl/2019/10/23/iqvia-podsumowaniewrzesien-2019/ (accessed on 12 March 2020).

28. Ministry of Science and Higher Education. Regulation of the Minister of Science and Higher Education on the Standards of Undergraduate Education of Physicians, Dentists, Pharmacists, Nurses, Midwives, Laboratory Diagnosticians, Physiotherapists and Paramedics. [in Polish: RozporządzenieMinistraNaukiiSzkolnictwaWyższego w SprawieStandardówKształceniaPrzygotowującegodo WykonywaniaZawoduLekarza, LekarzaDentysty, Farmaceuty, Pielęgniarki, Położnej, DiagnostyLaboratoryjnego, FizjoterapeutyiRatownikaMedycznego]. 2019. Available online: https:/isap.sejm.gov.pl/isap.nsf/download.xsp/ WDU20190001573/O/D20191573.pdf (accessed on 7 August 2020).

29. Ministry of Education. Regulation of the Minister of Education of 16 May 2019 on the Curricula for Occupational Education and Additional Skills in Selected Professions [in Polish: RozporządzenieMinistraEdukacjiNarodowej z Dnia 16 maja 2019 r. w SprawiePodstawProgramowychKształceniaw ZawodachSzkolnictwaBranżowegoOraz DodatkowychUmiejętnościZawodowych w ZakresieWybranychZawodówSzkolnictwaBranżowego]. 2019. Available online: https://dziennikustaw.gov.pl/DU/2019/991 (accessed on 10 August 2020).

30. Tully, M.P.; Beckman-Gyllenstrand, A.; Bernsten, C.B. Factors Predicting Poor Counselling about Prescription Medicines in Swedish Community Pharmacies. Patient Educ. Couns. 2011, 83, 3-6. [CrossRef] [PubMed]

31. Koehler, T.; Brown, A. A Global Picture of Pharmacy Technician and Other Pharmacy Support Workforce Cadres. Res. Soc. Adm. Pharm. 2017, 13, 271-279. [CrossRef] [PubMed]

32. Editorial Team. Pharmacies Are Not able to Stay on-Duty. There Is a Shortage of Personnel throughout Poland [in Polish:AptekiNiesa w StanieDyżurować. wCałejPolsceBrakujePersonelu] mgr.farm. 2020. Available online: https://mgr.farm/aktualnosci/apteki-nie-sa-w-stanie-dyzurowac-w-calej-polsce-brakuje-personelu/ (accessed on 3 August 2020).

33. Supreme Pharmaceutical Chamber. Educational Materials for Pharmacists. Available online: https: //www.nia.org.pl/2020/03/11/koronawirus-materialy-dla-farmaceutow/ (accessed on 12 March 2020).

34. Salter, S.M.; Karia, A.; Sanfilippo, F.M.; Clifford, R.M. Effectiveness of E-Learning in Pharmacy Education. Am. J. Pharm. Educ. 2014, 78, 83. [CrossRef] [PubMed]

35. Nesterowicz, K.; Librowski, T.; Edelbring, S. Validating E-Learning in Continuing Pharmacy Education: User Acceptance and Knowledge Change. BMC Med. Educ. 2014, 14, 33. [CrossRef] [PubMed]

36. Coppus, S.F.P.J.; Emparanza, J.I.; Hadley, J.; Kulier, R.; Weinbrenner, S.; Arvanitis, T.N.; Burls, A.; Cabello, J.B.; Decsi, T.; Horvath, A.R.; et al. A Clinically Integrated Curriculum in Evidence-Based Medicine for Just-in-Time Learning through on-the-Job Training: The EU-EBM Project. BMC Med. Educ. 2007, 7, 46. [CrossRef]

37. Amariles, P.; Ledezma-Morales, M.; Salazar-Ospina, A.; Hincapié-García, J.A. How to Link Patients with Suspicious COVID-19 to Health System from the Community Pharmacies? A Route Proposal. Res. Soc. Adm. Pharm. 2020, 1-2. [CrossRef]

38. Ooi, G.S.; Hassali, M.A.; Shafie, A.A.; Kong, D.C.M.; Mak, V.S.L.; Chua, G.N. Consumers' perspectives of Malaysian community pharmacists as health educators: A qualitative insight. J. Pharm.Pract. Res. 2017, 47, 186-192. [CrossRef]

39. Chen, Y.C.; Kiersma, M.E.; Abdelmageed, A. Evaluation of Student Perceptions of Standardized Patient Simulation on Patient Counseling Confidence during Introductory Pharmacy Practice Experiences. Curr. Pharm. Teach. Learn. 2015, 7, 811-818. [CrossRef]

40. Gierdys, W. Coronavirus. Pharmacists and Pharmaceutical Technicians on the Front Line. What Does Their Job Look Like Now? [in Polish: Koronawirus. FarmaceuciiTechnicyFarmaceutyczninaPierwszejLiniiFrontu. JakWyglądaTerazIchPraca?] MagazynAptekarski. 2020. Available online: https://www.aptekarski.com/ 89320-koronawirus-farmaceuci-i-technicy-farmaceutyczni-na-pierwszej-linii-frontu-jak-wyglada-terazich-praca (accessed on 5 August 2020). 
41. Van Mill, J.W.F.; Schulz, M. A Review of Pharmaceutical Care in Community Pharmacy in Europe. Harvard Health Policy Rev. 2006, 7, 155-168.

42. El Hajj, M.S.; AL-Saeed, H.S.; Khaja, M. Qatar Pharmacists' Understanding, Attitudes, Practice and Perceived Barriers Related to Providing Pharmaceutical Care. Int. J. Clin. Pharm. 2016, 38, 330-343. [CrossRef] [PubMed]

43. Ung, C.O.L. Community Pharmacist in Public Health Emergencies: Quick to Action against the Coronavirus 2019-NCoV Outbreak. Res. Soc.Adm. Pharm. 2020, 583-586. [CrossRef]

44. Wiedenmayer, K.; Summers, R.S.; Mackie, C.A.; Gous, A.G.S.; Everard, M. World Health Organization, Developing Pharmacy Practice: A Focus on Patient Care. 2006. Available online: http://www.fip.org/files/fip/ publications/DevelopingPharmacyPractice/DevelopingPharmacyPracticeEN.pdf (accessed on 15 July 2020).

45. The appeal of the President of the Supreme Pharmaceutical Chamber to the Minister of Healthto Take Action to Increase the Safety of Community Pharmacies' Staff. 2020. Available online: https://www.nia.org.pl/2020/ 03/12/naczelna-rada-aptekarska-apeluje-do-ministra-zdrowia/ (accessed on 7 September 2020).

46. Editorial Team. The Reimbursement of Flu Vaccines for Physicians and Teachers. What about pharmacists? [in Polish:RefundowaneSzczepionkinaGrypęDlaLekarzyiNauczycielia co z Farmaceutami?] mgr.farm. 2020. Available online: https://mgr.farm/aktualnosci/refundowane-szczepionki-na-grype-dla-lekarzy-inauczycieli-a-co-z-farmaceutami/ (accessed on 7 September 2020).

47. Pharmaceutical Chambers Act. [in Polish: Ustawa z Dnia 10 Stycznia 2008 r. o ZmianieUstawy o IzbachAptekarskich (Dz.U. Nr 47 Poz. 273 Dnia 19 Marca 2008)]. 2008. Available online: http://prawo.sejm. gov.pl/isap.nsf/download.xsp/WDU20080470273/T/D20080273L.pdf (accessed on 8 September 2020).

48. The Ordinance of the Minister of Health of 8 July 2020 on the Establishment of the Pharmaceutical Care Expert Team [in Polish: ZarządzenieMinistraZdrowia z Dnia 8 Lipca 2020 r. w SprawiePowołaniaZespołu do SprawOpiekiFarmaceutycznej]. Available online: http://dziennikmz.mz.gov.pl/\#/legalact/2020/49/ (accessed on 8 September 2020).

49. Chancellery of the Prime Minister. The draft of the Pharmacy Profession Act. 2020. Available online: https://www.gov.pl/web/premier/projekt-ustawy-o-zawodzie-farmaceuty (accessed on 8 September 2020).

50. Cerbin-Koczorowska, M.; Zielinska-Tomczak, L.; Waszyk-Nowaczyk, M.; Michalak, M.; Skowron, A. As the twig is bent, so is the tree inclined: A survey of student attitudes toward interprofessional collaboration supported with the curricula analysis. J.Interprof. Care 2019, 33, 636-644. [CrossRef] [PubMed]

51. Waszyk-Nowaczyk, M.; Nowaczyk, P.; Simon, M. Physicians' and patients' valuation of pharmaceutical care implementation in Poznan (Poland) community pharmacies. Saudi Pharm. J. 2014, 22, 537-544. [CrossRef]

52. Payroll Report 2020. Earnings in Pharmacies all Over Poland. [in Polish: Raportpłac 2020. Zarobki w Aptekach w CałejPolsce]. Available online: https://praca.farmacja.pl/sites/default/files/Raport_P\%C5\%82ac_ 2020.pdf (accessed on 8 September 2020).

53. Editorial Team. PLN 1000 Bonus for $100 \%$ Presence. Pharmacies Are Fighting for Staff [in Polish: 1000 złPremiiza 100 proc. Obecności. AptekiWalczą o Personel]. 2020. Available online: https://mgr.farm/aktualnosci/1000-zlpremii-za-100-proc-obecnosci-apteki-walcza-o-personel/ (accessed on 8 September 2020).

54. Deloitte Advisory Company 2018 Report: How to Introduce Pharmaceutical Care in Poland? The Role and Challenges of a Modern Pharmacy [in Polish: JakWprowadzić w PolsceOpiekęFarmaceutyczną? RolaiWyzwaniaWspółczesnejApteki]. Available online: https://www2.deloitte.com/content/dam/Deloitte/ pl/Documents/Reports/pl-raport-jak\%20wprowadzic-w-Polsce-opieke-farmaceutyczna.pdf (accessed on 8 September 2020).

55. Żak, K. Pharmaceutical care or professional advice? Barriers to the implementation of pharmaceutical care in Poland. Ekon. Wroctaw Econ. Rev. 2018, 24, 65-81. [CrossRef]

56. Krejcie, R.V.; Morgan, D.W. Determining Sample Size for Research Activities. Educ. Psychol. Meas. 1970, 38, 607-610. [CrossRef]

(C) 2020 by the authors. Licensee MDPI, Basel, Switzerland. This article is an open access article distributed under the terms and conditions of the Creative Commons Attribution (CC BY) license (http://creativecommons.org/licenses/by/4.0/). 